\title{
PENGARUH UPAH DAN TINGKAT PENDIDIKAN TERHADAP PENYERAPAN TENAGA KERJA DI PROVINSI JAMBI \\ Tahun 2010-2019
}

\author{
Yunie Rahayu \\ Dosen Tetap Universitas Muhammadiyah Jambi \\ Yunierahayu.2016@gmail.com
}

Ringkasan

Penelitian ini bertujuan untuk mengetahui apakah upah minimum dan tingkat pendidikan berpengaruh terhadap penyerapan tenaga kerja di Provinsi Jambi dari tahun 2010- 2019. Data penelitian yang digunakan adalah data time series dari 2010-2019 yang diperoleh dari BPS Propinsi Jambi. Penelitian ini menggunakan model regresi linier berganda. Berdasarkan hasil analisis regresi linier berganda, upah minimum dan tingkat pendidikan secara signifikan mempengaruhi Penyerapan Tenaga Kerja di Propinsi Jambi dari tahun 2010-2019. Berdasarkan hasil analisis, upah minimum memiliki koefisien positif dan secara parsial berpengaruh signifikan terhadap penyerapan tenaga kerja. Tingkat pendidikan memiliki koefisien positif dan secara parsial berpengaruh signifikan terhadap Penyerapan Tenaga Kerja di Propinsi Jambi. Sementara secara Simultan, Upah minimum dan Tingkat Pendidikan berpengaruh signifikan terhadap penyerapan tenaga kerja di Provinsi Jambi dari tahun 20102019.

Kata kunci: Upah Minimum, Tingkat Pendidikan, Penyerapan Tenaga Kerja

\section{PENDAHULUAN}

Problematika ketenagakerjaan di Indonesia tidak jauh berbeda dengan permasalahan ketenagakerjaan di Provinsi Jambi pada umumnya. Baik itu menyangkut tingkat pengangguran yang masih relative tinggi, maupun tingkat produktivitas tenaga kerja yang masih belum optimal. Salah satu tantangan terbesar adalah menciptakan lapangan kerja atau usaha yang layak bagi angkatan kerja yang harus diantisipasi dari sejak dini sebelum terjadi peningkatan karena perubahan struktur umur penduduk. Tantangan itu mencakup dua aspek sekaligus, yaitu penciptaan lapangan kerja baru bagi angkatan kerja yang belum bekerja, dan peningkatan produktivitas kerja bagi mereka yang sudah berkerja sehingga dapat memperoleh imbalan kerja yang memadai untuk dapat hidup secara layak atau decent living. Maka dari itu salah satu usaha yang dapat dilakukan oleh pemerintah dalam mengatasi permasalah ketenagakerjaan adalah memperbaiki sistem upah melalui kebijakan upah minimum. Berdasarkan ketentuan pasal 1 ayat 1 Undang-Undang Nomor 78 Tahun 2015, upah untuk hak pekerja atau buruh yang diterima dan dinyatakan dalam bentuk uang sebagai imbalan dari pengusaha atau pemberi kerja kepada pekerja atau buruh yang ditetapkan dan dibayarkan menurut suatu perjanjian kerja, kesepakatan, atau 
peraturan perundang-undangan, termasuk tunjangan bagi pekerja atau buruh dan keluarganya atas suatu pekerjan dan jasa yang telah dilakukan. Kebijakan upah di Indonesia merujuk pada standar kelayakan hidup bagi para pekerja. Undang Undang Repubik Indonesia No. 13/2003 tentang Tenaga Kerja menetapkan bahwa upah minimum harus didasarkan pada Standar Kebutuhan Hidup Layak (KHL). Dampak dari adanya penentuan upah minimum adalah bahwa pekerja berupah rendah terlindungi karena mendapatkan upah tidak di bawah rata - rata. Berikut ini perkembangan UMP Jambi dari tahun 2015 - 2019 yaitu :

Tabel 1. Perkembangan UMP Jambi 2015 -2019

\begin{tabular}{|c|c|c|}
\hline Tahun & UMP Jambi & Perkembangan(\%) \\
\hline 2015 & 1.710 .000 & - \\
\hline 2016 & 1.906 .950 & 12 \\
\hline 2017 & 2.063 .948 & 8 \\
\hline 2018 & 2.243 .718 & 9 \\
\hline 2019 & 2.423 .889 & 8 \\
\hline
\end{tabular}

Sumber: BPS Provinsi Jambi, Tahun 2019

Masalah lain adalah kualitas tenaga kerja yang rendah akibat minimnya tingkat pendidikan penduduk, mirisnya tenaga kerja pada tingkat tinggi pula yang seringkali terjerumus dalam lingkaran pengangguran, baik pengangguran terbuka maupun pengangguran terselubung. Hal ini disebabkan oleh penumpukan tenaga kerja terdidik di suatu tempat yang tidak bisa terkordinir oleh lapangan usaha yang tersedia. Akibatnya, banyak tenaga kerja bekerja dilapangan usaha yang tidak sesuai dengan pendidikan yang dimiliki serta harus menerima upah yang tidak sesuai dengan standar pendidikannya. Selain itu, banyak yang berpendidikan tinggi namun tidak diserap dalam dunia kerja karena tidak berkualitas atau tidak mempunyai skill dan lapangan pekerjaan yang tersedia tidak sesuai dengan keinginan para pencari kerja. Pendidikan yang dimiliki seseorang akan mempengaruhi produktivitas kerjanya. Karena dengan pendidikan inilah seseorang memiliki modal untuk melakukan produktivitas di dalam suatu pekerjaan yang sesuai kreteria yang diinginkan oleh suatu perusahaan. Dari segi pendidikan, maka sumber daya manusia yang belum bermutu itu, tidak mampu mengisi lowongan pekerjaan terutama pada bidang-bidang tertentu yang juga membutuhkan banyak tenaga kerja. 


\section{Gambar 1. Persentase Penduduk 15 Tahun Ke atas Berdasarkan Ijazah Tertinggi Yang Dimiliki di Provinsi Jambi}

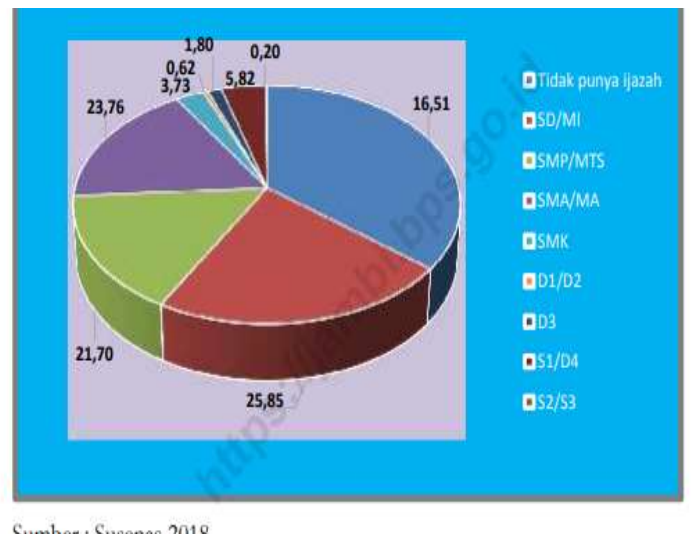

Dari gambar 1, persentase terbesar ketiga adalah penduduk dengan ijazah tertinggi yang dimiliki SMP Umum/Kejuruan/MTs, yaitu sebesar 21,70\%. Untuk penduduk dengan ijazah tertinggi SMA/MA memiliki persentase yang lebih Besar, yaitu sebesar 23,76\%. Sementara itu hanya sebagian kecil penduduk dengan ijazah tertinggi tingkat pendidikan yang lain, seperti SMK, diploma, dll.

Sementara itu kondisi ketenagakerjaan di Provinsi Jambi sejak tahun 2015 - 2019 adalah sebagai berikut :

Tabel 3 Kondisi Ketenagakerjaan Provinsi Jambi 2015-2019

\begin{tabular}{|c|r|r|r|r|r|}
\hline Jenis Kegiatan Tenaga & \multicolumn{5}{|c|}{ Tahun } \\
\cline { 2 - 6 } Kerja & \multicolumn{1}{|c|}{$\mathbf{2 0 1 5}$} & \multicolumn{1}{c|}{$\mathbf{2 0 1 6}$} & \multicolumn{1}{c|}{$\mathbf{2 0 1 7}$} & \multicolumn{1}{c|}{$\mathbf{2 0 1 8}$} & \multicolumn{1}{|c|}{$\mathbf{2 0 1 9}$} \\
\hline Bekerja & 1.550 .403 & 1.624 .52 & 1.657 .817 & 1.721 .362 & 1.691 .782 \\
\hline Pengangguran & 67.671 & 67.671 & 67.671 & 69.075 & 73.965 \\
\hline Angkata Kerja & 1.620 .752 & 1.692 .193 & 1.724 .633 & 1.790 .437 & 1.765 .747 \\
\hline Bukan Angkatan Kerja & 829.712 & 813.357 & 2.554 .395 & 824.853 & 906.184 \\
\hline TPA & 66.14 & 67.54 & 67.52 & 68.46 & 66.09 \\
\hline TPT & 4.34 & 4 & 3.87 & 3.86 & 4.19 \\
\hline
\end{tabular}

Sumber : BPS Provinsi Jambi, 2019

Berdasarkan tabel 3 menunjukkan, angkatan kerja dan penyerapan tenaga kerja di provinsi Jambi pada tahun 2015-2019 cendrung fluktuatif (tidak stabil). Angka angkatan kerja provinsi Jambi semakin naik dari tahun ke tahun pada tahun 2018 sebesar 1.721 .362 jiwa, penyerapan tenaga kerja mengalami penurunan angka paling rendah pada tahun 2014 sebesar 1.620.752 jiwa dan angka paling tinggi pada tahun 2018 sebesar 1.790 .437 jiwa namun jika dilihat dari tingkat pengangguran angka terendah tingkat penggangguran pada tahun 2015-2017 stabil dengan angka sebesar 67.671 jiwa dan angka pengangguran paling tinggi pada tahun 2019 sebesar 73.965 jiwa. 


\section{TINJAUAN TEORITIS}

\section{Tenaga Kerja}

Pengertian Tenaga Kerja Menurut Undang-Undang Republik Indonesia Nomor 13 Tahun 2003 tentang Ketenagakerjaan yang tercantum dalam Bab 1 Pasal 1 Ayat 2 menyebutkan, tenaga kerja adalah setiap orang yang mampu melakukan pekerjaan guna menghasilkan barang dan jasa baik untuk memenuhi kebutuhan sendiri maupun untuk masyarakat. Menurut Badan Pusat Statistik, tenaga kerja adalah penduduk usia kerja yang berumur 15 tahun atau lebih. Dengan demikian tenaga kerja di Indonesia dimaksudkan sebagai penduduk yang berumur 15 tahun atau lebih, sedangkan penduduk berumur dibawah 15 tahun digolongkan bukan tenaga kerja. Pasar tenaga kerja yaitu kegiatan dari pengusaha dan pencari kerja dengan bertemunya dalam lowongan kerja atau proses hubungan kerja, tenaga kerja yang telah masuk dalam usia kerja adalah 15-64 tahun (Putra, 2012).

Tenaga kerja berdasarkan kemampuannya terbagi menjadi 3 yaitu :

1. Tenaga kerja terdidik, Tenaga kerja terdidik yaitu suatu tenaga kerja yang mempunyai keahlian atau keterampilan di bidang tertentu dengan cara sekolah atau pendidikan formal dan informal. Contohnya : pengacara, dokter, guru, dan lain sebagainya.

2. Tenaga Kerja Terlatih, Tenaga kerja terlatih yaitu Personil Kerja yang dilatih tenaga kerja dengan keahlian di tertentu dengan melalui suatu pengalaman kerja. Kebutuhan tenaga kerja terampil diulang praktek sehingga menguasai pekerjaan. Contohnya pada : apoteker, ahli bedah, mekanik, dan lain sebagainya.

3. Tenaga Kerja Tidak Terdidik Dan Tidak Terlatih, Tenaga Kerja Tidak Terdidik Dan Tidak Terlatih merupakan Tenaga kerja terampil dan pekerja terampil dilatih untuk mengandalkan kekuatan sendiri. Contohnya pada : kuli, pelayan, dan lain sebagainya.

Sedangkan menurut Wijaya dan Suyana Utama (2013), penyerapan tenaga kerja dapat mempengaruhi efisiensi, dimana semakin efisien faktor produksi tenaga kerja yang digunakan maka semakin baik juga efisiensi usaha. Menurut Mankiw (2003), upah senantiasa menyesuaikan diri demi terciptanya keseimbangan antara penawaran dan permintaan tenaga kerja.Tingkat upah dan kuantitas tenaga kerja telah menyesuaikan diri guna menyeimbangkan permintaan dan penawaran. Ketika pasar berada dalam kondisi ekuilibrium, masing-masing perusahaan "membeli" tenaga kerja dalam jumlah yang menguntungkannya, berdasarkan harga atau upah ekuilibrium itu berarti setiap perusahaan telah merekrut pekerja dalam jumlah dimana nilai produk marjinal sama dengan upah. 


\section{Upah}

Pengertian upah menurut UU tenaga kerja No.13 tahun 2003 adalah hak pekerja/buruh yang diterima dan dinyatakan dalam bentuk uang sebagai imbalan dari pengusaha atau pemberi kerja kepada pekerja/buruh yang ditetapkan dan dibayarkan menurut suatu perjanjian kerja, kesepakatan, atau peraturan perundang-undangan termasuk tunjangan bagi pekerja/buruh dan keluarganya atas suatu pekerjaan atau jasa yang telah atau akan dilakukan.

Besaran upah menurut David Ricardo dalam (Purnami, 2015) tergantung pada keperluan subsistensi artinya besarnya upah yang ditetapkan mengikuti kebutuhan hidup minimum yang dibutuhkan para pekerja. Ketika standar umum kehidupan meningkat, maka upah yang dibayarkan kepada pekerja juga meningkat. Teori ini dikenal sebagai teori nilai kerja.

Menurut Adam Smith dalam (Purnami, 2015) menyatakan bahwa ketika terjadi kenaikan tingkat upah rata - rata, maka akan diikuti oleh turunnya jumlah tenaga kerja yang diminta sehingga terjadinya pengangguran. Sebaliknya, ketika turunnya tingkat upah rata - rata akan diikuti dengan meningkatnya jumlah tenaga kerja yang diminta. Teori Adam Smith juga menjelaskan adanya hubungan antara waktu bekerja dan pengalaman dengan upah. Tenaga kerja cenderung meningkatkan waktu kerja untuk menambah penghasilan. Namun jika tingkat upah sudah cukup tinggi, maka tenaga kerja akan mengurangi waktu bekerja dan menambah waktu istirahat.

\section{Tingkat Pendidikan}

Menurut Andrew E. Sikula dalam Mangkunegara (2003) tingkat pendidikan adalah suatu proses jangka panjang yang menggunakan prosedur sistematis dan terorganisir, yang mana tenaga kerja manajerial mempelajari pengetahuan konseptual dan teoritis untuk tujuan-tujuan umum. Dengan demikian Hariandja menyatakan bahwa tingkat pendidikan seorang karyawan dapat meningkatkan daya saing perusahaan dan memperbaiki kinerja perusahaan. Menurut UU SISDIKNAS No. 20 (2003), indikator tingkat pendidikan terdiri dari jenjang pendidikan dan kesesuaian jurusan. Jenjang pendidikan adalah tahapan pendidikan yang ditetapkan berdasarkan tingkat perkembangan peserta didik, tujuan yang akan dicapai, dan kemampuan yang dikembangkan, terdiri dari:

\section{METODE PENELITIAN}

Metode penelitian yang digunakan adalah deskriptif kuantitatif. Metode deskriptif adalah metode penelitian yang bertujuan untuk membuat gambaran meng/enai situassi atau kejadian, sedangkan analisis kuantitatif adalah metode analisis yang melakukan perhitungan terhadap 
data-data yang bersifat pembuktian dari masalah. Sehingga metode deskriptif kuantitatif adalah metode penelitian yang memamparkan atau menjelaskan data melalui angka-angka. Data yang digunakan dalam penelitian ini adalah data sekunder, yaitu data diperoleh secara tidak langsung dari sumbernya, seperti dari website dan buku dalam angka di Badan Pusat Statistik (BPS) Provinsi Jambi, antara lain Provinsi Jambi Dalam Angka, Produk Domestik Regional Bruto (PDRB) Provinsi Jambi.

Alat analisis data yang digunakan dalam penelitian ini Regresi Linear Berganda yaitu untuk mengukur pengaruh upah dan tingkat pendidikan terhadap penyerapan tenaga kerja di Provinsi Jambi antara lebih dari satu variabel bebas terhadap variabel terikat. Untuk menghitung regresi linier berganda dapat dituliskan dengan rumus sebagai berikut :

$$
\begin{aligned}
& \mathrm{Y}=\beta_{0}+\beta_{1} \mathrm{X}_{1}+\beta_{2} \mathrm{X}_{2}+\mathrm{e} \\
& \text { Keterangan : } \\
& \mathrm{Y} \quad=\text { Penyerapan Tenaga Kerja } \\
& \beta_{0} \quad=\text { Koefisien } \\
& \beta_{1,} \beta_{2}=\text { Koefisien Regresi } \\
& \mathrm{X} 1 \quad=\text { Upah } \\
& \mathrm{X} 2 \quad=\text { Tingkat Pendidikan } \\
& \mathrm{e} \quad=\text { Standart Error }
\end{aligned}
$$

Uji F digunakan untuk mengetahui pengaruh variabel bebas secara bersama-sama (simultan) terhadap variabel terikat. Jika $\mathrm{F}_{\text {hitung }}<\mathrm{F}_{\text {tabel }}$ 5\% maka $\mathrm{H}_{\mathrm{O}}$ diterima dan $\mathrm{H}_{1}$ menolak yang artinya variabel independen secara serentak atau bersama-sama tidak mempengaruhi variabel dependen secara signifikan.

Uji T digunakan untuk mengetahui besarnya signifikan pengaruh variabel bebas terhadap variabel terikat secara individual (parsial). Dengan menganggap variabel lain bersifat konstanta. Jika $t_{\text {hitung }}>\mathrm{t}_{\text {tabel }} 5 \%$ maka $\mathrm{H}_{\mathrm{O}}$ ditolak dan $\mathrm{H}_{1}$ diterima yang artinya salah satu variabel bebas (independen) mempengaruhi variabel terikat (dependen) secara signifikan.

\section{HASIL PEMBAHASAN}

\section{Perkembangan Upah Minimum Provinsi}

Kebijakan pemerintah tentang penetapan upah minimum dapat berpengaruh terhadap angka pengangguran. Oleh karena itu pemerintah harus benar-benar mempertimbangkan dengan baik kebijakan dalam menetapkan tingkat upah. Tujuan utama ditetapkannya upah 
minimum adalah memenuhi standar hidup minimum seperti kesehatan, efisiensi dan kesejahteraan pekerja. Semakin meningkat tingkat upah minimum akan meningkatkan pendapatan masyarakat sehingga kesejahteraan juga meningkat dan sehingga terbebas dari kemiskinan. Secara umum, kondisi upah minimum di Provinsi Jambi mengalami peningkatan dari tahun ketahun seiring dengan semakin tingginya harga berbagai macam kebutuhan hidup masyarakat. Perkembangan tingkat Upah Minimum Provinsi yang berlaku di Provinsi Jambi terlihat mengalami peningkatan setiap tahunnya. Hal ini dapat dilihat pada tabel 4 berikut:

Tabel 4 Perkembangan Upah Minimum Provinsi (UMP) Di Provinsi Jambi Tahun 2010-2019

\begin{tabular}{|c|c|c|c|}
\hline No. & Tahun & UMP (Rupiah) & Perkembangan (\%) \\
\hline 1 & 2010 & 900.000 & - \\
\hline 2 & 2011 & 1.028 .000 & 14 \\
\hline 3 & 2012 & 1.142 .500 & 11 \\
\hline 4 & 2013 & 1.300 .000 & 14 \\
\hline 5 & 2014 & 1.502 .230 & 16 \\
\hline 6 & 2015 & 1.710 .000 & 14 \\
\hline 7 & 2016 & 1.906 .650 & 12 \\
\hline 8 & 2017 & 2.063 .948 & 8 \\
\hline 9 & 2018 & 2.243 .719 & 9 \\
\hline 10 & 2019 & 2.400 .000 & 7 \\
\hline \multicolumn{4}{|c|}{ Rata-Rata } \\
\hline
\end{tabular}

Sumber : BPS Provinsi Jambi, Tahun 2019

Berdasarkan tabel 4 menunjukkan bahwa perkembangan UMP di Provinsi Jambi sejak tahun 2010-2019 cendrung meningkat dengan rata-rata perkembangan per tahun sebesar 12\%. Provinsi Jambi harus terus memperbaiki kondisi yang ada pada tenaga kerjanya agar upah yang diterapkan juga dapat sesuai dengan kebutuhan hidup layak pekerja sehingga kesejahteraan pekerja pun dapat tercapai. Dampak dari adanya penentuan upah minimum adalah bahwa pekerja berupah rendah terlindungi karena mendapatkan upah tidak di bawah rata - rata. Kenaikan upah tenaga kerja tersebut dapat mengurangi jam kerja lemburnya karena dengan naiknya upah akan menambah pendapatannya. Namun dengan kenaikan upah minimum tersebut akan berdampak pada penyerapan tenaga kerja yang berkurang, karena dengan naiknya upah akan menambah biaya-biaya dalam perusahaan sehingga perusahaan mengurangi jumlah tenaga kerja. Penyerapan tenaga kerja sangatlah penting karena jika suatu wilayah tenaga kerja yang terserap rendah dan tidak tersedianya lapangan kerja maka akan meningkatnya pengangguran yang akan berakibat pada kemiskinan yang tinggi. Upah yang sesuai akan membuat bekerja secara profesional, namun jika upah yang diterima tergolong di 
bawah rata - rata maka tenaga kerja tersebut akan meninggalkan perusahaan untuk memperoleh upah di perusahaan lain yang lebih baik.

\section{Perkembangan Tingkat Pendidikan}

Selama periode 2010-2019 tingkat pendidikan di Provinsi Jambi yang tercermin dari rata-rata lama bersekolah menunjukkan kecendrungan yang meningkat, sebagaimana tergambar pada tabel berikut ini:

Tabel 5 Rata-rata Lama Sekolah menurut Kabupaten/Kota di Provinsi Jambi Tahun 2010-2019

\begin{tabular}{|c|c|c|}
\hline Tahun & Rata-rata lama bersekolah & Perkembangan (\%) \\
\hline 2010 & 7,34 & - \\
\hline 2011 & 7,48 & 1.90 \\
\hline 2012 & 7,69 & 2.80 \\
\hline 2013 & 7,80 & 1.43 \\
\hline 2014 & 7,92 & 1.53 \\
\hline 2015 & 7,96 & 0.50 \\
\hline 2016 & 8,07 & 1.38 \\
\hline 2017 & 8,15 & 0.99 \\
\hline 2018 & 8,23 & 0.98 \\
\hline 2019 & 8,45 & 2.67 \\
\hline \multicolumn{2}{|r|}{ Rata-rata } & 2 \\
\hline
\end{tabular}

Sumber : BPS Provinsi Jambi, Tahun 2019

Pada tabel 5 terlihat bahwa rata-rata lama bersekolah diatas menunjukan peningkatan di setiap tahunnya. Secara rata-rata selama periode 2010-2019 laju pertumbuhan tingkat pendidikan di Provinsi Jambi adalah sebesar 2\%. Rata-rata lama sekolah di Provinsi Jambi tingkat pendidikan yang ditamatkan merupakan salah satu ukuran kualitas sumber daya manusia. Semakin tinggi tingkat pendidikan yang ditamatkan, semakin baik pula kualitas sumber daya manusia. Sehingga potensi sumber daya manusia di suatu Provinsi dilihat dari jenjang pendidikan yang ditamatkannya. Sumber daya manusia yang berkualitas diharapkan mampu memperbaiki dan meningkatkan pertumbuhan perekonomian di suatu Provinsi.

\section{Perkembangan Penyerapan Tenaga Kerja Di Provinsi Jambi}

Jumlah penduduk yang bekerja menjadi cerminan tingkat kemakmuran suatu negara. Semakin besar presentase penduduk bekerja maka kemungkinan akan semakin besar kesejahteraan pendudukdalam suatu wilayah. Hal ini disebabkan dengan mereka bekerja dapat memenuhi kebutuhan mereka yang mereka inginkan. 
Untuk meningkatan penyerapan tenaga kerja maka pemerintah telah berupaya memacu pertumbuhan ekonomi pada setiap sektor. Hal ini tentu saja diharapkan semakin membuka peluang kesempatan kerja dan berusaha yang lebih besar pada masyarakat. Penciptaan kesempatan kerja merupakan salah salah sasaran pembangunan ekonomi dan sekaligus menjadi instrumen utama dalam pemertaan hasil-hasil pembangunan. Secara makro ekonomi, perkembangan kesempatan kerjanasional dipengaruhi oleh pertumbuhan ekonomi nasional. Dengan demikian dapat dikatakan bahwa jumlah kesempatakn kerja yang tersedia dalam kurun waktu tertentu merupakan cerminan dari daya dukung ekonomi dalam penggunaan sumberdaya manusiayang tersedia.

Peningkatan kegiatan ekonomi daerah diberbagai sektor akan memberikan dampak baik langsung maupun tidak langsung terhadapat penciptaan lapangan kerja. Tanggung jawab ideal dari dunia kerja adalah bagaimana dapat menyerap sebesar- besarnya tambahan angkatan kerja baru yang terjadi setiap tahun, dengan memperhatikan berbagai aspek peningkatan produktivitas tenaga kerja. Untuk lebih jelasnya penyerapan tenaga kerja di Provinsi Jambi dapat dilihat pada tabel 6 :

\section{Tabel 6 Perkembangan Penyerapan Tenaga Kerja}

Di Provinsi Jambi Tahun 2010-2019

\begin{tabular}{|c|c|c|}
\hline Tahun & Tenaga Kerja & Perkembangan (\%) \\
\hline 2010 & 1.360 .022 & 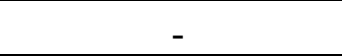 \\
\hline 2011 & 1.434 .998 & 5,51 \\
\hline 2012 & 1.423 .624 & $(0,79)$ \\
\hline 2013 & 1.382 .471 & $(2,89)$ \\
\hline 2014 & 1.491 .038 & 7,85 \\
\hline 2015 & 1.550 .403 & 3,98 \\
\hline 2016 & 1.624 .522 & 4,78 \\
\hline 2017 & 1.657 .817 & 2,04 \\
\hline 2018 & 1.721 .362 & 3,83 \\
\hline 2019 & 1.691 .782 & $(1,71)$ \\
\hline \multicolumn{2}{|c|}{ Rata-rata } & 2,51 \\
\hline
\end{tabular}

Sumber : BPS Provinsi Jambi, Tahun 2019

Tabel 6 menunjukkan bahwa selama periode 2010-2019 orang yang bekerja di Provisi Jambi menunjukkan kecendrungan yang terus meningkat. Pada tahun 2010 jumlah orang yang bekerja mampu diserap adalah sebesar 1.360.022 jiwa. Namun sampai 2019 sudah mencapai 1.691.782 jiwa. Pertumbuhan penyerapan tenaga kerja tertinggi terjadi pada tahun 2014, yaitu sebesar 7,85\%. Sementara laju pertumbuhan penyerapan tenaga kerja terendah terjadi pada 
tahun 2012, yaitu sebesar -0,79\%. Secara rata-rata selama periode 2010-2019 laju pertumbuhan penyerapanan tenaga kerja di Provinsi Jambi adalah sebesar 2,51\%.

Penduduk usia kerja yang semakin bertambah seiring penduduk yang meningkat dari tahun ketahunnya mengakibatkan bertambahnya penawaran tenaga kerja. Hal ini dapat menimbulkan peluang bekerja yang semakin kecil saat lapangan pekerjaan yang tersedia semakin sedikit, sehingga timbulnya persaingan didunia kerja baik pencari kerja maupun pekerja yang harus mempertahankan pekerjaannya. Dari data diatas dapat dilihat bahwa terjadi pertambahan kesempatan kerja dari tahun 2010 hingga tahun 2019, dimana orang yang bekerja bertambah 2,51\% rata-rata pertahun . Tingginya kebutuhan akan tenaga kerja tersebut berarti ada kesempatan kerja bagi orang yang menganggur, Pasar tenaga kerja, seperti pasar lainnya dalam perekonomian dikendalikan oleh kekuatan penawaran dan permintaan, namun pasar tenaga kerja berbeda dari sebagian besar pasar lainnya karena permintaan tenaga kerja merupakan tenaga kerja turunan (derived demand) dimana permintaan akan tenaga kerja sangat tergantung dari permintaan akan output yang dihasilkannya.

Pengaruh Upah dan Tingkat Pendidikan Terhadaap Penyerapan Tenaga Kerja di Provinsi Jambi

Berdasarkan hasil pengujian sebagaimana terlampir pada lampiran maka diperoleh hasil-hasil sebagai berikut :

Tabel 7 Hasil-hasil Koefisien Regresi Dan Nilai-nilai t Hitung Coefficients $^{\mathrm{a}}$

\begin{tabular}{|c|c|c|c|c|c|c|c|}
\hline \multirow[b]{2}{*}{ Model } & \multicolumn{2}{|c|}{$\begin{array}{l}\text { Unstandardized } \\
\text { Coefficients }\end{array}$} & \multirow{2}{*}{\begin{tabular}{|c|}
$\begin{array}{c}\text { Standardized } \\
\text { Coefficients }\end{array}$ \\
Beta \\
\end{tabular}} & \multirow[b]{2}{*}{$\mathrm{t}$} & \multirow[b]{2}{*}{ Sig. } & \multicolumn{2}{|c|}{$\begin{array}{c}95,0 \% \text { Confidence } \\
\text { Interval for B }\end{array}$} \\
\hline & B & $\begin{array}{l}\text { Std. } \\
\text { Error }\end{array}$ & & & & $\begin{array}{l}\text { Lower } \\
\text { Bound }\end{array}$ & $\begin{array}{l}\text { Upper } \\
\text { Bound }\end{array}$ \\
\hline (Constant) & $-7,105$ & ,666 & & $-10,666$ &, 000 & $-8,680$ & $-5,530$ \\
\hline Upah & ,976 & ,414 & ,425 & 2,354 & ,051 &,- 004 & 1,955 \\
\hline Pendidikan & 9,988 & 3,130 & ,576 & 3,191 & 015 & 2,587 & 17,389 \\
\hline
\end{tabular}

a. Dependent Variable: TK

Berdasarkan tabel 7 maka dapat disusun model persamaan regresi linier berganda sebagai berikut:

$$
\begin{aligned}
& \mathrm{Y}=-7.105+0,976 \mathrm{X}_{1}+9,988 \mathrm{X}_{2}+\mathrm{e} \\
& \mathrm{X}_{1}=\text { Upah } \\
& \mathrm{X}_{2}=\text { Tingkat Pendidikan } \\
& \mathrm{b}_{1}=0,976 \\
& \mathrm{~b}_{2}=9,988
\end{aligned}
$$

Hasil persamaan regresi di atas memiliki konstanta sebesar -7,105 yang dapat diinterpretasikan bahwa ketika upah minimum provinsi dan jumlah tenaga kerja berdasarkan 
tingkat pendidikan adalah konstan, maka nilai penyerapan tenaga kerja mengalami penurunan sebesar $-7,105 \%$. Koefisien regresi untuk variabel upah adalah 0,976 artinya upah berpengaruh positif terhadap penyerapan tenaga kerja di Provinsi Jambi. Jika tingkat upah minimum dinaikkan 1\% dengan asumsi cateris paribus, maka terjadi peningkatan penyerapan tenaga kerja sebesar $0,976 \%$. Hasil perhitungan koefesien regresi bernilai positif berarti terjadi hubungan positif antara upah minimum dengan penyerapan tenaga kerja. Jika jumlah upah minimum semakin bertambah maka akan meningkatkan jumlah penyerapan tenaga kerja, dan sebaliknya jika jumlah upah minimum berkurang maka akan menurunkan jumlah penyerapan tenaga kerja. Sedangkan koefisien regresi untuk variabel tingkat pendidikan adalah 9,988. Jika tingkat pendidikan dinaikan 1\% dengan asumsi cateris paribus, maka dapat diperkirakan bahwa terjadi peningkatan penyerapan tenaga kerja sebesar 9,988\%. Hasil perhitungan koefesien regresi bernilai positif berarti terjadi hubungan positif antara tingkat pendiidkan dengan penyerapan tenaga kerja. Semakin meningkat tingkat pendidikan, maka penyerapan tenaga kerja akan meningkat. Semakin menurun tingkat pendidikan maka penyerapan tenaga kerja semakin menurun.

\section{Hasil Uji Hipotesis}

a. Uji Simultan (Uji F)

Uji F digunakan untuk pengujian terhadap variabel-variabel independen secara bersama-sama yang dilakukan untuk melihat pengaruh variabel independen secara individu terhadap variabel dependen. Untuk mengetahui signifikan atau tidak berpengaruh secara bersama-sama variabel bebas terhadap variabel terikat maka digunakan probability sebesar 5\% (0.05).

Uji F bisa dilihat dari:

1. Jika nilai Sig $<\alpha$ maka Ho ditolak

2. Jika nilai Sig $>\alpha$ maka Ho diterima

Berdasarkan hasil analisis, diketahui nilai $\mathrm{F}_{\text {hitung }}$ adalah sebesar 34,944. Karena nilai $F_{\text {hitung }} 34,944>F_{\text {tabel }}$ 4,46, maka sebagaimana dasar pengambilan keputusan dalam uji $\mathrm{F}$ dapat disimpulkan bahwa hipotesis diterima atau dengan kata lain upah $\left(\mathrm{X}_{1}\right)$ dan tingkat pendidikan $\left(\mathrm{X}_{2}\right)$ secara simultan berpengaruh terhadap penyerapan tenaga kerja $(\mathrm{Y})$.

b. Uji Parsial (Uji t)

Untuk melihat secara parsial pengaruh masing-masing variabel independen terhadap penyerapan tenaga kerja di Provinsi Jambi. 
1. Pengaruh upah

Berdasarkan hasil analisis logaritma regresi linier berganda diperoleh nilai $t_{\text {hitung }}$ untuk variabel pengaruh upah adalah sebesar 2,354 dengan tingkat keyakinan 5\% $(\alpha=0,05)$ diperoleh $t_{\text {tabel }}$ sebesar 1,943, sehingga dapat diketahui bahwa thitung lebih besar dari tabel $(2,354>1,943)$, maka $\mathrm{H}_{0}$ ditolak dan menerima $\mathrm{H}_{\mathrm{a}}$. Artinya terdapat pengaruh signifikan antara upah terhadap penyerapan tenaga kerja di Provinsi Jambi.

2. tingkat pendidikan

Berdasarkan hasil analisis logaritma regresi linier berganda diperoleh nilai $t_{\text {hitung }}$ untuk variabel tingkat pendidikan adalah sebesar 3,191 dengan tingkat keyakinan 5\% $(\alpha=0,05)$ diperoleh $\mathrm{t}_{\text {tabel }}$

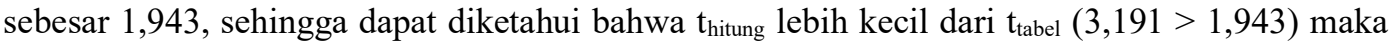
$\mathrm{H}_{\mathrm{a}}$ diterima dan menolak $\mathrm{H}_{0}$. artinya terdapat pengaruh yang signifikan antara tingkat pendidikan terhadap penyerapan tenaga kerja di Provinsi Jambi.

\section{Pengujian Koefisien Korelasi}

Koefisiel korelasi digunakan untuk melihat apakah terdapat hubungan yang kuat antara variabel bebas, yaitu upah $\left(\mathrm{X}_{1}\right)$ rata-rata lama bersekolah $\left(\mathrm{X}_{2}\right)$ dengan penyerapan tenaga kerja di Provinsi Jambi. Dari model hasil analisis linier berganda yang diperoleh, dapat dilihat apakah model regresi linier berganda tersebut merupakan garis pendugaan yang tepat. Untuk itu perlu dilihat nilai koefisien kolerasinya $(\mathrm{R})$.

\section{Tabel 8 Hasil Uji Korelasi}

Model Summary

\begin{tabular}{|c|c|c|c|c|}
\hline & $\mathrm{R}$ & R Square & $\begin{array}{l}\text { Adjusted R } \\
\text { Square }\end{array}$ & $\begin{array}{l}\text { Std. Error of } \\
\text { the Estimate }\end{array}$ \\
\hline 1 & $994^{\mathrm{a}}$ & ,988 & ,985 & 0422 \\
\hline
\end{tabular}

a. Predictors: (Constant), Pendidikan, Upah

Dari hasil perhitungan diperoleh nilai korelasi $\mathrm{R}$ adalah 0,994 atau 99,4\% menunjukkan nilai koefisien korelasi yang tinggi atau hubungan yang sangat erat antara variabel tingkat pendidikan dan upah Provinsi Jambi. Melalui tabel ini juga diperoleh nilai R Square atau koefisien determinasi yang menunjukkan seberapa bagus model regresi yang dibentuk oleh interaksi variabel bebas dan variabel terikat. Nilai koefisien determinasi yang diperoleh adalah 0,988 atau 98,8\% yang ditafsirkan bahwa tingkat pendidikan dan upah memiliki pengaruh kontribusi sebesar 99,8\% terhadap penyerapan tenaga Kerja. 


\section{KESIMPULAN DAN SARAN}

\section{Kesimpulan}

Berdasarkan hasil dari pembahasan yang telah dilakukan, maka dapat ditarik beberapa kesimpulan, yaitu :

1. Perkembangan rata-rata penyerapan tenaga kerja di Provinsi Jambi tahun 2010-2019 sebesar $2,51 \%$. Perkembangan penyerapan tenaga kerja tertinggi pada tahun 2014 yaitu sebesar $7,85 \%$ dan perkembangan penyerapan tenaga kerja terendah terjadi pada tahun 2012 yaitu sebesar $0,79 \%$ dari tahun sebelumnya.

2. Secara parsial, upah minimum berpengaruh signifikan terhadap penyerapan tenaga kerja dan pengaruhnya berbentuk positif, yaitu apabila upah minimum meningkat maka akan meningkatkan penyerapan tenaga kerja dan sebaliknya. Sementara itu, tingkat pendidikan berpengaruh signifikan terhadap penyerapan tenaga kerja dan pengaruhnya berbentuk positif, yaitu apabila tingkat pendidikan meningkat maka akan meningkatkan penyerapan tenaga kerja dan sebaliknya

3. Secara simultan, upah minimum dan tingkat pendidikan berpengaruh signifikan terhadap penyerapan tenaga kerja

\section{Saran}

Dapat penulis kemukakan beberapa saran sebagai berikut :

1. Tenaga kerja merupakann salah satu sasaran pembangunan ekonomi dan sekaligus menjadi instrumen utama dalam pemerataan hasil pembangunan untuk itu diharapkan pemerintah dapat menciptakan lapangan kerja baru yang dibutuhkan agar semua lapisan masyarakat dapat terserap dalam pasar kerja.

2. Pemerintah daerah perlu mengatasi masalah pengupahan dan juga diharapkan mampu mendorong peningkatan penyerapan tenaga kerja di Provinsi Jambi dengan meningkatkan upah tenaga kerja. Peningkatan ini bisa dilakukan dengan memberikan insentif atau bonus kepada tenaga kerja. Sehingga dapat meningkatkan kesejahteraan para pekerja tanpa mengorbankan kepentingan pengusaha.

3. Pemerintah diharapkan lebih memperhatikan pendidikan dan menata kembali seluruh sistem pendidikan yang disesuaikan dengan kebutuhan lapangan pekerjaan yang ada. Sehingga lulusan untuk jenjang pekerjaan menurut tingkat pendidikan dapat disalurkan dan untuk lulusan pendidikan tinggi tidak lagi memilih-milih pekerjaan, karena sudah tersalurkan. 


\section{DAFTAR PUSTAKA}

Afrida. 2003. Ekonomi Sumberdaya Manusia. Ghalia Indonesia: Jakarta.

Buchori, I. 2016. Pengaruh Upah Minimum Dan Tingkat Pendidikan Terhadap Penyerapan Tenaga Kerja Sektor Industri Manufaktur Di Pulau Sumatera Tahun 2012-2015. EKSIS Volume 11, No 1. Universitas Negeri: Jakarta.

Effendi, T. 2005. Permenpan No, PER/66/M.PAN/2005 Tentang Jabatan Fungsional Widyaiswara dan Angka Kreditnya, Menpan: Jakarta.

Kuncoro, M. 2002. Sistem Bagi Hasil dan Stabilitas Penyerapan Tenaga Kerja: Jurnal Ekonomi Pembangunan, vol.7 Universitas Negeri: Jakarta.

Kuncoro, M. 2003. Ekonomi Pembangunan : Teori, Masalah, dan Kebijakan. UPP AMP YKPN: Yogyakarta.

Mangkunegara, A.P. 2003. Perencanaan dan Pengembangan Sumber Daya Manusia. Refika Aditama: Bandung.

Mankiw, G.N. 2003 ,Pengantar Ekonomi edisi kedua jilid ke 1. Penerbit Erlangga: Jakarta.

Mulyadi. 2014. Ekonomi Sumber Daya Manusia Dalam Perspektif Pembangunan, PT. Raja Grafindo Persada: Jakarta.

Sandi, D.R. (2013). "Pengaruh Tingkat Pendidikan dan PDRB Terhadap Penyerapan Tenaga Kerja Pada Usaha Sektor Pertanian Di Kabupaten Jombang". Sekolah Tinggi Keguruan dan Ilmu Pendidikan Persatuan Guru Republik Indonesia: Jombang.

Sekigawa, M.J. 2012. Makalah Kuliah: Ketenagakerjaan.STKS: Bandung.

Simanjuntak, P.J. 2008. Pengantar Ekonomi Sumberdaya Manusia, Lembaga Penerbit Fakultas Ekonomi Universitas Indonesia: Jakarta.

Soleh, A. (2017). Masalah ketenagakerjaan dan pengangguran di Indonesia. Jurnal Ilmiah Cano Ekonomos, 6(2), 83-92.

Soleh, A., \& Maryoni, H. S. (2017). Analisis Sektor Ekonomi Unggulan dan Hubungannya dengan Kesempatan Kerja dan Investasi di Kabupaten Batanghari. Jurnal Ekonomi$Q u, 7(1)$.

Jambi, A. S. D. S. M. (2018). Peran Desentralisasi Fiskal Terhadap IPM dan Penyerapan Tenaga Kerja di Kota Jambi.

Sumarni, M. 2014. Pengantar Bisnis Dasar-Dasar Ekonomi Perusahaan: Yogyakarta.

Todaro, M.P., \& Stephen, C.S. 2006. Pembangunan Ekonomi, Edisi Kesembilan. Munandar, Haris (penerjemah), Erlangga: Jakarta. 
Umar, T., \& Sulo, L.A. 2005. Pengantar pendidikan (edisi revisi) PT Rineka Cipta: Jakarta.

Indonesia, P. R. (2006). Undang-Undang Republik Indonesia Nomor 13 Tahun 2003 Tentang Ketenagakerjaan.

Wahyudi, A. 2004. Ekonomi Pembangunan, Cetakan Pertama, Ghalia Indonesia: Jakarta.

Wijaya, C. 2013. Pengaruh Teknologi Terhadap Penyerapan, Pendapatan, Produktivitas dan Efisiensi Usaha Pada Industri Kerajinan Genteng di Desa Pejaten. Fakultas Ekonomi dan Bisnis Universitas Udayana: Bali. 